Global Sustainability

cambridge.org/sus

\section{Intelligence Briefing}

Cite this article: Hofmann M, Bergamasco F (2020). Space resources activities from the perspective of sustainability: legal aspects. Global Sustainability 3, e4, 1-7. https://doi.org/ $10.1017 /$ sus.2019.27

Received: 29 November 2018 Revised: 9 December 2019

Accepted: 9 December 2019

Author for correspondence:

Prof Dr Mahulena Hofmann,

E-Mail: mahulena.hofmann@uni.lu

\title{
Space resources activities from the perspective of sustainability: legal aspects
}

Mahulena Hofmann (D) and Federico Bergamasco

University of Luxembourg, Faculty of Law, Economics and Finance, rue Alphonse Weicker 4, L-2721 Luxembourg

\section{Non-technical abstract}

The new forms of the use of outer space, such as space resources activities, not only will provide a vital contribution to research and industry, but could also entail a negative impact to the space environment. The present article aims at discussing from a legal perspective crucial problems such as how we shall ensure that the entities active in the area of space resources take environmental concerns into account, how we shall ensure that they utilize the best possible and least invasive technology and whether they should restore the 'mining' area when finishing their tasks.

\section{Technical abstract}

Space resources activities present numerous opportunities for expanding the exploration and use of outer space, but they could also involve environmental risks. The purpose of the present article is to navigate across such risks from a regulatory perspective and to investigate the potential solutions. The final findings relate to three fundamental questions: How shall we ensure that the entities active in the area of space resources take the space environment into account? How shall we ensure that they utilize the best possible and least invasive technology? And should they restore the 'mining' area when finishing their tasks? To this purpose, an overview on the planned space resources activities will first be provided, together with a summary of the involved entities. Subsequently, the analysis will shift to the legal framework, starting with the main international treaties and the related applicable principles. It will then move onto national legislations. The concluding remarks will indicate an international framework as the most suitable solution to the problem of environmental sustainability, taking into considerations existing models and proposals.

\section{Social media summary}

Legal issues of the environmental aspects of space resources activities and solutions for regulatory gaps are discussed.

\section{Introduction ${ }^{\mathrm{i}}$}

Due to the new forms of the use of outer space as space resources activities, not only their contribution to research and industry, but also their potential negative impacts on the environment are discussed: How shall we ensure that the entities active in the area of space resources take the space environment into account? How shall we ensure that they utilize the best possible and least invasive technology? And should they restore the 'mining' area when finishing their tasks?

The more general question of how to ensure the sustainability of space activities emerged within the context of the proliferation of space actors and the intensification of the uses of outer space over the last 10 years. The main deliberations on these issues took place in the UN Committee on the Peaceful Uses of Outer Space (UN COPUOS), which agreed upon a set of recommendatory guidelines for the long-term sustainability of outer space activities in 2016 (UN COPUOS, 2018a). Recent plans to exploit the mineral resources found on the celestial bodies - on the Moon and asteroids - have only intensified these discussions.

This contribution focuses on the environmental aspect of these future space resources activities and observes it from its legal perspective. The objects of analysis are the selected UN space treaties, the US and Luxembourg domestic legislation on space resources and the principles elaborated by the international The Hague Space Resources Governance Working Group.

\section{Space resources activities: overview}

In several countries, intense activities on space resources exploitation and extraction have developed in recent years. In the USA, Planetary Resources, Inc., came forward with a plan 
to transform asteroid water into rocket fuel and eventually to harvest platinum-group metals from space rocks (Planetary Resources, 2018; Wall, 2015). Before its acquisition by Bradford Space Group, Deep Space Industries had a project to change the economics of the space industry by providing the technical resources, capabilities and system integration required to prospect for, harvest, process, manufacture and market in-space resources (Bradford Space Group, 2018).

For Japan, space resources development may be a promising industry in the future (Mizushima et al., 2017), as symbolized by the Hayabusa Project, in which a spacecraft operated by the Japanese Aerospace Exploration Agency succeeded in landing on the surface of a small near-Earth asteroid, returning samples of the materials back to Earth (JAXA, 2018). There are also reports stating that China is planning to exploit resources such as titanium, helium-3 and water from the far side of the Moon, where its first module landed in January 2019 (Goswami, 2016). Its Chang'e lunar exploration programme is an ongoing robotic mission to the Moon based on the White Papers on China's Space Activities (Shouping, 2017) led by the China National Space Administration. There is also information available showing that investments are being made in asteroid exploration (Mizushima et al., 2017). Additionally, space resources programmes are being pursued in the United Arab Emirates (Gulfnews, 2017).

In Luxembourg, the Government announced its 'Space Resources.lu' initiative in February 2016, which is a series of measures "to position Luxembourg as a European hub in the exploration and use of space resources." One of the central elements of this policy was the development of a legal and regulatory framework confirming certainty about the future ownership of minerals extracted in space (Luxembourg Space Agency, 2019b). To foster international cooperation, the Government of Luxembourg concluded bilateral cooperation agreements with Portugal (2017), United Arab Emirates (2017), Japan (2017), China (2017), Czech Republic (2018), Poland (2018), Belgium (2019) and the USA (2019) aimed at the exchange of information and the strengthening of bilateral relations in the field of space activities (Luxembourg Space Agency, 2019a).

\section{International legal framework of space resources activities}

The expansion of space resources activities, even in its research and development stage, was not welcome everywhere, and not simply because of environmental concerns.

As an example, the Russian Federation, which in 2013 included space resources mining in its key political document in the area of space activities approved by the President of the Federation called 'The Keystones of State Policy of Russian Federation in the Area of Space Activities for the Period till 2030 and with a Further Perspective' (Russian Federation, 2013), surprised us by turning into one of the most active critics of these projects, especially in the UN COPUOS (2016). Whereas currently the position of Russia seems to be more muted than in 2016, Belgium - one of the 18 States Parties of the 1979 Moon Agreement - remains the leader of the countries that see these activities as violations of international law (UN COPUOS, 2017a). The working document submitted to the Legal Subcommittee of the UN COPUOS in 2019 by Belgium and Greece, proposing to establish a working group for the development of an international regime for the utilization and exploitation of space resources, contains inter alia a thesis on the "potentially disruptive economic impact" of space resources exploitation activities on existing global inequality, and it proclaims that only a new international governance framework is a precondition for a "lawful and sustainable exploitation" of space resources (UN COPUOS, 2019a).

The proliferation of space resources projects also led to passionate discussion in academia. Whereas some authors started deliberating on how to develop practicable rules for the implementation of these programmes (Blount \& Robinson, 2016; Ganatra \& Modi, 2015-2016; Frank, 2017; Gangale, 2015-2016; Mizushima et al., 2017; von der Dunk, 2017; White, 2003), others saw in these activities a violation of international legal rules (Cocca, 1996; De Man, 2016, 2017; Gorove, 1969; Hobe \& De Man, 2017; Kelly, 2004; Roth, 1992; Tronchetti, 2014; Volynskaja, 2016).

The positions regarding space mining have been divided in principle along two main lines of inquiry: first, whether space resources projects are compatible with the non-appropriation principle of the 1967 Treaty on Principles Governing the Activities in the Exploration and Exploitation of Outer Space, including the Moon and Other Celestial Bodies - more commonly known as the Outer Space Treaty (OST); and second, do these projects comply with the "province of mankind" requirements as embodied in Article I OST? In comparison with these questions, the issue of respect for the environments of celestial bodies and the Earth by the space resources operators seems to be less controversial at the moment; however, it could turn into a battlefield on the details of environmental protection in the future.

\subsection{Prohibition of the appropriation of outer space}

Because of its very high level of recognition among States (UN COPUOS, 2017b) and its customary character (Hobe et al., 2017; von der Dunk, 2015), the 1967 OST became the central international legal source of the law of outer space. One of its key provisions is Article II, which states that "outer space, including the Moon and other celestial bodies, is not subject to national appropriation by claim of sovereignty, by means of use or occupation, or by any other means."

For the opponents of space mining, this provision means that nothing in outer space might be 'appropriated' because, in their view, any extraction - whether by a State or a non-governmental entity - of any material from any celestial body necessarily implies a kind of such 'appropriation' (Volynskaja, 2016). Another chain of arguments is based on the differentiation between various forms of activities in outer space provided by Article I OST, which separates the freedoms of its "exploration" and "use," also including "exploitation" of outer space (De Man, 2017). If there are no constraints on the exploration of outer space, then any ownership of space minerals would imply the prevention of others from using the same matter; by this logic, only the use of outer space without property rights to space resources could correspond to international law (De Man, 2017).

This thread of argumentation is considered to be further supported by the existence of the later adopted 1979 Agreement Governing the Activities of States on the Moon and Other Celestial Bodies (Moon Agreement). In line with this postulate, it prohibits, in its Article 11(3), that any "natural resources in place" shall become the property of any entity or person 
(De Man, 2017). From this prohibition are exempted only undefined "samples" of minerals from celestial bodies, which may be used for scientific purposes, as well as "minerals and other substances" of celestial bodies used in "quantities appropriate for the support of the missions" of the States Parties of the Agreement (Article 6).

However, the purpose of space mining activities is considered to be neither any 'appropriation' of parts of outer space nor of space resources in situ. Instead, the sole aim of any such activities is their extraction, use and commercialization, without any territorial demands or titles as to the celestial bodies (or parts thereof) concerned (Mizushima et al., 2017).

The argument, which sees in the use or exploitation of a space mineral by one subject a limitation of the same right of another subject, is difficult to contest by other means than analogy with space exploration. As has been recognized by the drafters of the OST in its Articles IX and XII, a purely scientific project in one area of outer space could de facto prevent research at the same site by a subject from another State. To avoid such situations, the Treaty pre-envisages a system of international consultations aimed at avoiding any harmful interference with operations.

It should also be stressed that the Moon Agreement has been ratified by only 18 States Parties (UN COPUOS, 2019b); thus, its limitations concerning space activities resulting from the common heritage principle are binding only upon its Parties, and it cannot constitute international customary law. Additionally, there is a Joint Statement of its States Parties dating from 2008 and proclaiming that the common heritage of mankind principle does not constitute an obstacle to space mining initiatives (UN COPUOS, 2008).

Finally, this liberal line of thought points to the legal regime of the High Seas under the 1982 UN Convention on the Law of the Sea (UNCLOS) and, in particular, to the regulation of fishing, which allows the States Parties, in principle, to freely fish on the High Seas. This is a relevant analogy with space resources. Article 87 UNCLOS grants States Parties of the treaty the freedom to fish on the High Seas, subject to specific conditions in "due regard for interests of other States in their exercise of the freedom of the high seas." Furthermore, Article 116 UNCLOS postulates that "all States have the right for their nationals to engage in fishing in the high seas," subject to their treaty obligations and the rights and duties of coastal States (Freestone, 2009; Wright et al., 2016).

There are also discussions as to whether the term 'celestial bodies' should be redefined. Currently, according to the International Astronomical Union, known natural objects that can be found in the solar system include the Sun, the planets, the Moon, the moons of other planets, near-Earth objects, asteroids, comets, dwarf planets, trans-Neptunian objects and Kuiper Belt objects (Lyall \& Larsen, 2009). Discussions on these categorizations have resulted in proposals to exclude smaller asteroids under a minimum diameter from the term 'celestial body' (Marboe \& Friedl, 2019), which would eliminate those from the prohibition of appropriation.

\subsection{Outer space as 'province of all mankind'}

According to Article I OST, the freedom of exploration and the use of the Moon and other celestial bodies are "the province of all mankind." The Cologne Commentary on Space Law considers this rule as "one of the most important, but also of the most disputed provisions of the entire Outer Space Treaty" (Hobe et al., 2009), and it concludes that the notion of "province of mankind" brings this lead provision of the Treaty "in line with the legal regulation of human activities in other common spaces, such as activities on the High Seas and the Deep-Sea Bed" (Hobe et al., 2009).

The 1979 Moon Agreement reiterates the "province of mankind" principle (Article 4). However, the Moon, celestial bodies and their natural resources are additionally declared by Article 11(1) to be "the common heritage of mankind" (CHM). This principle can be understood as an idea of intergenerational equity in that it couples the preservation of the environment with its use by future generations (Jakhu et al., 2013). However, the Cologne Commentary refers to the fact that "there is no unique feature or specific meaning of the CHM in all its manifestations." While different interpretations may be put forward, the proper meaning of the CHM can only be determined in the context of its use and for the purpose of the future applicable regulatory regime (Jakhu et al., 2013).

In the body of the Moon Agreement, in addition to CHM's relation to the prohibition of the appropriation of natural resources on celestial bodies in Article 11(3), this principle finds its expression in Article 11(5), which envisages the establishment of an international regime to govern the exploitation of these resources when "such exploitation is about to become feasible." This obligation can be interpreted as a duty of its States Parties to make good faith efforts to convene an international conference and to negotiate for the purpose of reaching an agreement; "however, they would not be bound to reach an agreement on an international regime," and the proposed international conference might even "reject the principle CHM, or give it a new and liberal scope" (Jakhu et al., 2013).

The modification mechanisms of both treaties (Article XV resp. 17) or the convening of an international conference as envisaged by Article 18 of the Moon Agreement have not yet been called upon. In 1994, 10 years after the entry into force of the Moon Agreement, the Resolution of the UN General Assembly A/RES/49/34 of 30 January 1995 took note of the recommendation of the UN COPUOS that the General Assembly, at its current session, in considering whether to revise the Moon Agreement, should not take any action (paragraph 42). The present discussions about the future international regime shall be described below.

\subsection{Protection of the environment}

Parallel to the questions of the appropriation of space resources and the future international regime, there are already several provisions of the UN space treaties that are relevant for the protection of the environment of outer space and that frame the way in which space 'mining' might be performed in the future. It can be stated, however, that those norms are of a general character and cover only a small part of the whole spectrum of space resources activities.

Article IX OST requires that States pursue studies of outer space, including the Moon and other celestial bodies, and conduct exploration of them so as to avoid their harmful contamination. At the same time, it obliges spacefaring nations to avoid adverse changes in the environment of the Earth resulting from the introduction of extra-terrestrial matter and, when necessary, to adopt appropriate preventative measures. The problem is the narrow scope of application of this obligation. A literal interpretation of the second paragraph limits the duty of States Parties to avoid harmful contamination only in the pursuance of "studies of outer space" and "space exploration." 
Second, the core element of the second paragraph is the concept of "harmful contamination" and the related duty upon States Parties to avoid it. However, it is not sufficiently precise as to which type of degradation of the outer space environment is prohibited and to what extent (Kramer, 2014). The presence of the term 'harmful' suggests at first that contamination is not per se prohibited, and thus that exploration activities are lawful even if, to a limited degree, contamination is caused (Lyall, 2010). In addition, the term 'contamination' lacks a definition. This seemingly leaves it open to cover both biological and non-biological kinds of contamination, thus encompassing the release of chemical and radioactive contaminants (Lyall, 2010). However, it hardly covers environmental modifications of different kinds, such as the alteration of the topography and geology of a celestial body, which could be a consequence of large-scale human activities such as space mining. The generic terms 'appropriate measures' and 'where necessary' further water down any rigorous content of the obligation.

These problems are partially remedied by the 1979 Moon Agreement, whose Article 7(1) concerns environmental protection. It widens the scope of Article IX OST by explicitly including the "exploitation" phase of space activities and by stating the duty of States Parties to "prevent the disruption of the existing balance" of the environment of celestial bodies. Such disruption can take place through the introduction of "adverse changes," through its "harmful contamination through the introduction of extraenvironmental matter," or "otherwise." Although the concept of the 'harmful contamination' of celestial bodies remains undefined, it is beyond doubt that these specifications give a more substantial meaning to the provision. As stated above, however, the Moon Agreement has a very limited number of States Parties.

More details about the implementation of Article IX OST and Article 7 of the Moon Agreement can be found in the Planetary Protection Policy formulated by the Committee on Space Research (COSPAR), a Scientific Committee of International Council for Science (ICSU) established in 1958. The updated policy (COSPAR, 2005) recommends the adoption of specific measures that should be taken before and after space missions (e.g., to meet specific criteria on spacecraft cleanliness). These measures are differentiated in the extent to which the specific target body (e.g., the planet or an asteroid) is of interest for understanding the origins and evolution of life (Hofmann, 2010). The formal limitation of COSPAR standards consists in the fact that - as in Article IX OST - they concentrate on scientific research, not on commercial space activities; furthermore, they do not go beyond the protection of outer space and the Earth against biological contamination. It has been discussed, however, how the scope of the policy could be extended in the future.

\section{National legislation on space resources from the sustainability perspective}

The OST and the Moon Agreement impose obligations to their respective States Parties without any direct impact to non-state actors (e.g., operators of space resources activities). However, one of the crucial and specific principles of international space law, Article VI OST, declares that States Parties shall bear international responsibility for all national activities in outer space independently of the whether they are performed by themselves or by non-state entities. Moreover, space activities of nongovernmental entities require "authorization and continuous supervision by the appropriate State Party." This provision led to the adoption of the numerous space legislations throughout the world that regulate the conditions and procedures of such authorizations (UNOOSA, 2019). Some of these laws include aspects of sustainability and environmental protection as one of the preconditions for obtaining this authorization.

\subsection{General national space legislation protecting sustainability}

As an example, the US national space law comprises the National Environmental Policy Act (United States, 1970), which must be complied with by space missions during their launch and re-entry phases. It requires the Federal Aviation Administration's Office of Commercial Space (FAA AST) to integrate environmental values into its decision-making processes concerning commercial launch or re-entry activities (FAA AST, 2019).

Other examples are the Russian 1993 Law on Space Activity (Russian Federation, 1993), which requests all participants in space activities to take any necessary measures in order to avoid any threat to the environment.

Environmental criteria are part of the licensing procedures inter alia the 1986 UK Act on Outer Space Activities (United Kingdom, 1986), the 1998 Australian Space Activities Act (Commonwealth of Australia, 1998, 2019), the 2005 Belgian Law on the Activities of Launching, Flight Operation or Guidance of Space Objects (Belgium, 2014), the 2006 Space Activities Act of The Netherlands (The Netherlands, 2006), the French Law on Space Activities (Article 4) of 2008 (France, 2008), the Austrian Act on Authorization of Space Activities and the Establishment of a National Space Registry of 2011 (Austria, 2011), the Danish Outer Space Act of 2016 (Denmark, 2016) and the 2018 Finnish Act on Space Activities (Finland, 2018).

The Government of Luxembourg prepared a general Draft Law on Space Activities in 2018, which is being discussed in Parliament within the present legislative period (for the current state of the legislation, see Chambre des Députés, 2019). The project contains provisions dealing with the protection of the environment; for example, if the space activity authorized by the respective Minister of Luxembourg would amount in a danger for a non-specified 'environment', the authorization can be withdrawn (Article 9). However, with the exception of launch activities and space object registration, space resources activities are exempted from the scope of this general Draft Law (Article 2).

\subsection{Specific space resources legislation}

In view of the planned intensity of space resources activities, first the USA and later Luxembourg adopted specific legislation devoted to these projects.

The 2015 US Commercial Space Launch Competitiveness Act (United States, 2015) made the USA the first country to have adopted a national regulatory framework for space mining activities. Its aim is to "facilitate commercial exploration for and commercial recovery of space resources by United States citizens" (\$ 51302). The Act defines a "space resource" as an "abiotic resource in situ in outer space," including minerals and water ( $\$ 51301$ (2)), and an "asteroid resource" as a "space resource found on or within a single asteroid” ( $\$ 51301(1)$ ). Title IV of the Act authorizes citizens of the USA "to possess, own, transport, use, and sell the asteroid resource or space resource" that they 
obtain "in accordance with applicable law, including the international obligations of the United States" ( $\$ 51303$ ).

The Act does not contain any specific provision dealing with the sustainability of space resources activities. The National Environmental Policy Act (United States, 1970) is focused on launch and re-entry activities only. However, the commercial exploration and recovery of space resources by US citizens should be "consistent with the international obligations of the United States" ( $\$ 51302$ (a)). Consequently, the conditions of Article IX OST cannot be ignored.

The 2017 Law on the Exploration and Use of Space Resources of Luxembourg was inspired by the US model. The law was adopted on 27 July 2017 and entered into force on 2 August 2017. The legislation deals generally with "space resources" without making a distinction between space and asteroid resources. Article 1 of the Law declares that "space resources are capable of being appropriated." Article 16 of the Law deals with the "responsibility for damage." According to this provision, the operator is fully responsible for any damage caused at the occasion of the mission, including all preparatory works and duties.

The Law does not explicitly mention the environmental criteria among the conditions that have to be met when applying for the authorization of the space resources mission. Similarly to the US Law, Article 2(2) of the Law states that an authorized operator may only "carry out the activity" in space resources area "in accordance with ... the international obligations of Luxembourg." As in case of the USA, this obligation leads to Article IX OST and - even if only implicitly - to the obligation to comply with its planetary protection provisions.

\section{An international regime: solution for sustainability}

From the perspective of the sustainability of space activities in relation to space 'mining', the optimal solution would be an international regime giving the States guidance when authorizing space resources missions. The question is: by whom and how should this regime be shaped?

It is questionable whether the model of the deep seabed based on Part XI of the United Nations Convention on the Law of the Sea of 1982 is the best example to follow. Until now, only a very limited number of contracts have been concluded, and there are good reasons to question whether the existing complicated and expensive structure is an attractive pattern to be followed, especially for developing countries.

A different approach is followed by the multi-stakeholder The Hague Space Resources Governance Working Group, which published in November 2019 the 'Building Blocks for the Development of an International Legal Framework on Space Resources Activities' (The Hague Space Resources Working Group, 2019). In this document, this international group - composed of representatives of several governments, academia and future space resources operators - stressed that a future international framework should create an enabling environment for space resources activities. This framework must be consistent with international law, should promote consistency and predictability among domestic frameworks of States and internal frameworks of intergovernmental organizations and should prevent disputes arising out of space resources activities (Building Block (BB) 4).

From the perspective of sustainability, it should first be underlined that the scope of the BBs is limited to activities conducted in outer space, not on the Earth. Concerning space activities, the framework suggested by the document should, inter alia, contribute to sustainable development (BB $4.2 \mathrm{c}$ ) and promote the use of sustainable technology (BB $4.2 \mathrm{~g}$ ). BB 10 is specifically devoted to the "avoidance and mitigation of potentially harmful impacts resulting from space resources activities." It requires that States and intergovernmental organizations authorizing space resources activities adopt appropriate measures with the aim of avoiding their harmful impacts, including risks to the environment (BB $10 \mathrm{a}$ ), damage to the environment (BB $10 \mathrm{~b}$ ), adverse changes in the environment of the Earth (BB $10 \mathrm{c}$ ), harmful contamination of celestial bodies (BB $10 \mathrm{~d}$ ) and outer space (BB $10 \mathrm{e}$ ), as well as harmful interference with other ongoing space activities (BB $10 \mathrm{~g}$ ). These measures should take into account the internationally agreed planetary protection policies elaborated by COSPAR (BB $10 \mathrm{c}$ and $\mathrm{d}$ ).

To prevent such harmful changes, the expected international framework should provide that a review of the safety and avoidance of harmful impacts prior to the authorization of space resources activities is required by the States and international organizations authorizing them (BB 11). BB 12 is devoted to the monitoring and redressing of harmful impacts resulting from space resources activities. The envisaged international framework should provide that States and intergovernmental organizations shall monitor whether any harmful impacts result from space resources activities for which they are responsible (BB 12.1). If such a harmful impact occurs, the States and international organizations shall "implement measures to respond to such harmful impact (response measures) and consider whether the space resource activity should be adjusted or terminated" (BB 12.2). The future international repository established on the basis of the Article XI OST should collect information inter alia on "any harmful impact resulting from space resources activities" and "the measures planned or implemented to redress such impacts" (BB 14 e and v).

This document should, in the formulation of The Hague BBs, serve as a basis for negotiations on an intentional framework and recommendations for an implementation strategy (BB Introduction). It will be interesting to see the extent to which these practical propositions shall influence the present discussions on space resources activities in the UN COPUOS, especially in its Legal Sub-Committee in the framework of the item 'General Exchange of views on potential legal models for activities in exploration, exploitation and utilization of space resources' (UN COPUOS, 2018b).

\section{Conclusion}

In the introduction to our analysis, the following questions were raised: How shall we ensure that the entities active in the area of space resources take the space environment into account? How shall we ensure that they utilize the best possible and least invasive technology? And should they restore the 'mining' area when finishing their tasks? Our overview demonstrated that there were several complementary paths for influencing the behaviour of space resources operators by means of law.

First, it is Article IX OST that stipulates that States shall avoid harmful contamination of the Earth and outer space. Naturally, the addressees of this provision are not space resources operators, but 'States'; however, if domestic legislation, such as that of the USA and Luxembourg, requires that the operators may only carry out their activities in accordance with the international obligations of the respective State, the need for compliance of the activities of the operators with the norms of Article IX OST is 
inevitable. It is in our view less important that these provisions are vague and hardly enforceable in international law (Apking, 2005).

Second, as long as there is no international regime regulating space resources activities, domestic laws seem to be the most effective tools for ensuring the compliance of operators with the sustainability and environmental criteria. The most feasible instrument for the implementation of Article IX OST is the domestic authorization procedure based on Article VI OST. The State authorities could make the environmental criteria of space activities to be one of the conditions of their authorization and objects of their control and supervision. Once part of the national procedure, compliance with Article IX OST can be enforced by means of domestic law, and also, in extremis, through the withdrawal of an authorization.

Third, the future international regime (e.g., as suggested by The Hague Space Resources Governance Working Group) may have a considerable impact on the activities of operators. Its strong emphasis on the protection of the environment during and after space resources activities is a very positive signal for the future. The BBs not only suggest that States should take environmental criteria into account when authorizing and supervising space resources missions, but they also propose additional measures, such as the duty to submit information about harmful impacts resulting from space resources activities to a publicly accessible international repository. The present status of the document has been discussed above; here, it should be stressed that it was not imposed on space resources operators, but - quite to the contrary - it was developed together with them.

Finally, the environmental provisions of the OST were developed on the basis of solidarity among the members of the international research community and the need to avoid compromising the results of space research. The motives of the present generation of space resources operators, who have grown up within the global sustainability discourse, to collaborate in the drafting of the rules protecting the 'clean' use of celestial bodies might be similar. In the end, it can be an advantage for all not to impair the environment of outer space as a good that is available for the use of all.

Acknowledgements. The authors would like to express their gratitude to $\mathrm{Dr}$ P. J. Blount for his indispensable assistance in the editing phase of this paper.

Author contributions. The two authors have contributed equally to this paper.

Financial support. None.

Conflicts of interest. None.

Ethical standards. This research and article complies with Global Sustainability's publishing ethics guidelines.

\section{Note \\ i The article is a continuation of the research published in Hofmann and Bergamasco (2018).}

\section{References}

Apking, A. G. (2005). The rush to develop space: the role of spacefaring nations in forging environmental standards for the use of celestial bodies for governmental and private interests. Colorado Journal of International Environmental Law and Policy, 16, 429.
Blount, P. J. \& Robinson, C. J. (2016). One small step: the impact of the US Commercial Space Launch Competitiveness Act of 2015 on the exploitation of resources in outer space. North Carolina Journal of Law \& Technology, $18,1$.

Bradford Space Group (2018). Bradford Space Group Acquires Control of Deep Space Industries, Inc. Retrieved from https://www.bradford-space. com/news2019-01-02.php.

Chambre des Députés (2019). 7317 - Projet de loi sur les activités spatiales et portant modification de la loi modifiée du 9 juillet 1937 sur l'impôt sur les assurances. Retrieved from https://www.chd.lu/wps/portal/public/Accueil/ TravailALaChambre/Recherche/RoleDesAffaires?action=doDocpaDetails\& backto=/wps/portal/public/Accueil/TravailALaChambre/Recherche/Aucun Resultat\&id $=7317$.

Cocca, A. (1996). Property rights on the Moon and other celestial bodies. In Proceedings of the Thirty-Ninth Colloquium on the Law of Outer Space (pp. 9-19). American Institute of Aeronautics and Astronautics.

COSPAR (2005). COSPAR Planetary Protection Policy. Retrieved from http://w.astro.berkeley.edu/ kalas/ethics/documents/environment/COSPAR \%20Planetary\%20Protection\%20Policy.pdf.

De Man, P. (2016). Exclusive Use in an Inclusive Environment: The Meaning of the Non-appropriation Principle for Space Resource Exploitation. Springer.

De Man, P. (2017). Luxembourg Law on Space Resources Rests on Contentious Relationship with International Framework. KU Leuven Working Paper No. 189.

FAA AST (2019). Environmental Program. Retrieved from https://www.faa. gov/about/office_org/headquarters_offices/ast/environmental.

Frank, R. J. (2017). International and domestic laws on commercial use of space mineral resources. Presented at 68th International Astronautical Congress, Adelaide, Australia, 25-29 September.

Freestone, D. (2009). Fisheries, High Seas. Max Planck Encyclopedia of Public International Law.

Ganatra, D. \& Modi, N. (2015-2016). Asteroid mining and its legal implications. Journal of Space Law, 40, 81.

Gangale, T. (2015-2016). The legality of mining celestial bodies. Journal of Space Law, 40, 187.

Gorove, S. (1969). Interpreting Article II of the Outer Space Treaty. Fordham Law Review, 37, 349.

Goswami, N. (2016). China's Unique Space Ambitions. The Diplomat. Retrieved from https://thediplomat.com/2016/08/chinas-unique-spaceambitions.

Gulfnews (2017). Space-mining may be only a decade away. Retrieved from https://gulfnews.com/business/sectors/technology/space-mining-may-beonly-a-decade-away-1.2019210.

Hobe, S. \& De Man, P. (2017). National Appropriation of Outer Space and State Jurisdiction to Regulate the Exploitation, Exploration and Utilization of Space Resources. ZLW Sonderdruck.

Hobe, S., Schmidt-Tedd, B. \& Schrogl, K-U. (eds.) (2009). Cologne Commentary on Space Law, Vol. I. Heymanns Verlag GmbH.

Hobe, S., Schmidt-Tedd, B. \& Schrogl, K-U. (eds.) (2013). Cologne Commentary on Space Law, Vol. II. Heymanns Verlag GmbH.

Hofmann, M. (2010). Planetary protection from a legal perspective: due diligence and national legislation. In IAA Cosmic Study: Protecting the Environment of Celestial Bodies (pp. 51-53). International Academy of Astronautics (IAA).

Hofmann, M. \& Bergamasco, F. (2018). Mining in outer space: legal aspects. In M. Bungenberg et al. (eds.), European Yearbook of International Economic Law 2018 (EYIEL) (pp. 313-334). Springer.

Jakhu, R., Freeland, S., Hobe, S. \& Tronchetti, F. (2013). Article 11 (Common Heritage of Mankind/ International Regime). In S. Hobe, B. Schmidt-Tedd \& K.-U. Schrogl et al. (eds.), Cologne Commentary on Space Law Vol. II (pp. 388-399). Heymanns Verlag GmbH.

JAXA (2018). Hayabusa Project: Science Data Archive. Retrieved from https:// darts.isas.jaxa.jp/planet/project/hayabusa.

Kelly, R. (2004). Nemitz v. United States, a case of first impression: appropriation, private property rights and space law before the Federal Courts of the United Sates. Journal of Space Law, 30, 297.

Kramer, W. R. (2014). Extraterrestrial environmental impact assessment - a foreseeable prerequisite for wise decisions regarding outer space exploration, research and development. Space Policy, 30, 215-222. 
Luxembourg Space Agency (2019a). Press Release Archive. Retrieved from https://space-agency.public.lu/en/news-media/press-release.html.

Luxembourg Space Agency (2019b). Space Resources. Retrieved from https:// spaceresources.public.lu/en.html.

Lyall, F. (2010). Planetary protection from a legal perspective - general issues, in protecting the environment of celestial bodies. In IAA Cosmic Study: Protecting the Environment of Celestial Bodies (pp. 45-50). International Academy of Astronautics (IAA).

Lyall, F. \& Larsen, P. B. (2009). Space Law: A Treatise. Routledge.

Marboe, I. \& Friedl, M. (2019). What are space resources? What are celestial bodies? - The need for refined legal definitions in view of recent regulatory efforts concerning space resources. In P. J. Blount, R. Moro-Aguilar, T. Masson-Zwaan \& K.-U. Schrogl (eds.), 2018 Proceedings of the IISL (pp. 749-760). Eleven.

Mizushima, A., Fujii, K. \& Ishido, S. (2017). What is an Appropriate Interaction between International Law and Domestic Legal Systems to Promote Space Resources Development? Kluwer Law International BV.

Planetary Resources (2018), About the Exploration Program. Retrieved from https://www.planetaryresources.com/missions/arkyd-301.

Roth, D. (1992). La prohibition de l'appropriation et les régimes d'accès aux espaces extra-terrestres, Graduate Institute Publications.

Russian Federation (1993). Decree No. 5663-1 of the Russian House of Soviets.

Russian Federation (2013). Document No. Pr-906, approved by the President of the Russian Federation on 19 April 2013.

Shouping, L. (2017). China. IISL Directorate of Studies, Background Paper. International Institute of Space Law.

The Hague Space Resources Working Group (2019). Building Blocks for the Development of an International Legal Framework on Space Resources Activities. Retrieved from https://www.universiteitleiden.nl/binaries/content/ assets/rechtsgeleerdheid/instituut-voor-publiekrecht/lucht--en-ruimterecht/ space-resources/hisrgwg_building-blocks-for-space-resource-activities.pdf.

Tronchetti, F. (2014). Private property rights on asteroid resources: assessing the legality of the Asteroids Act. Space Policy, 30, 193-196.

UN COPUOS (2008). Joint Statement on the benefits of adherence to the Agreement Governing the Activities of States on the Moon and Other Celestial Bodies of 1979 by States Parties to that Agreement, UN Doc. A/AC.105/C.2/2008/CRP.11.

UN COPUOS (2016). Document on the 53rd Session of the Scientific and Technical Subcommittee of UN COPUOS, UN Doc. A/AC.105/C.1/2016/ CRP.15.
UN COPUOS (2017a). Contribution from Belgium to the discussion under UN COPUOS Legal Subcommittee on item 'General exchange of views on potential legal models for activities in exploration, exploitation and utilization of space resources', UN Doc. A/AC.105/C.2/2017/CRP.19.

UN COPUOS (2017b). Status of International Agreements relating to activities in outer space as at 1 January 2017, UN Doc. A/AC.105/C.2/ 2017/CRP.7.

UN COPUOS (2018a). The Hague Space Resources Governance Working Group: Information provided by the Netherlands, UN Doc. A/AC.105/ C.2/2018/CRP. 18 .

UN COPUOS (2018b). Questions and observations by Belgium on the establishment of national legal frameworks for the exploitation of space resources, UN Doc. A/AC.105/C.2/2018/CRP.8.

UN COPUOS (2019a). Proposal for the establishment of a working group for the development of an international regime for the utilization and exploitation of space resources, UN Doc. A/AC.105/C.2/L.311.

UN COPUOS (2019b). Status of International Agreements relating to activities in outer space as at 1 January 2019, A/AC.105/C.2/2019/CRP.3.

UNOOSA (2019). National Space Law Collection. Retrieved from http://www. unoosa.org/oosa/en/ourwork/spacelaw/nationalspacelaw/index.html.

United States (1970). 91 Pub. L. 190 (1970) codified at 42 U.S.C.4321et seq.

United States (2015). US Commercial Space Launch Competitiveness Act, HR 2262.

Volynskaja, O. (2016). Space resources exploitation from the international and domestic law perspectives, the Russian approach. In Proceedings of the International Institute of Space Law (pp. 291-300). Eleven.

von der Dunk, F. (2015). Handbook of Space Law. Edward Elgar Publishing.

von der Dunk, F. (2017). Asteroid mining: international and national legal aspects. Michigan State International Law Review, 26, 1.

Wall, M. (2015). Asteroid Mining May Be a Reality by 2025. Retrieved from https:// www.space.com/30213-asteroid-mining-planetary-resources-2025.html.

White, W. N. (2003). Interpreting Article II of the Outer Space Treaty. In 46th Proceedings of the Colloquium on the Law of Outer Space (pp. 171-188). Eleven.

Wright, G., Rochette, J., Blom, L., Currie, D., Durussel, C., Gjerde, K. \& Unger, S. (2016). High seas fisheries: what role for a new international instrument? IDDRI Studies. Retrieved from http://publications.iasspotsdam.de/pubman/item/escidoc:1636893:9/component/escidoc:1636894/ 1636893.pdf. 